\title{
Kiellettyä tutkimassa - erikoisten kokemusten äärellä
}

\author{
Honkasalo, Marja-Liisa \& Kaarina Koski (toim.) 2017: Mielen rajoilla. Arjen \\ kummat kokemukset.
}

Helsinki: SKS. 360 sivua.

\author{
Leila Jylhänkangas
}

\begin{abstract}
$M$ ielen rajoilla (2017) tarkastelee nykykulttuurissa esiintyviä kummia tai erikoisia kokemuksia yli kahdensadan spontaanisti kirjoitetun kirjeen valossa. Kyseessä on tieteidenvälinen kokoomateos, joka käsittelee nykyajan kummia kokemuksia "sellaisina kuin ne on kerrottu ja muuten esitetty, pohdittu tai leimattu" (s. 12). Marja-Liisa Honkasalo esittelee kirjan johdannossa arkiymmärryksen ylittävien kokemusten yleisyyttä ja luonnetta. Tällaiset "kummat" kokemukset voivat käsittää erilaisia aistimellisia kokemuksia, kuten näkyjä, kuuloaistimuksia ilman äänen lähdettä tai kuolleiden kohtaamisia ja keskusteluja heidän kanssaan.
\end{abstract}

Teoksen johdannossa esitellään myös Mieli ja toinen -tutkimushanketta, jossa toimivat tutkijat ovat halunneet ottaa vakavasti aineistonsa äänet arvottamatta niissä kuvailtua todellisuutta. Tämä kytkeytyy läheisesti edellä mainitun hankkeen eettiseen tehtävään. Ihmisten kertomien kokemusten vakavasti ottaminen on tarkoittanut sitä, että kirjeaineistosta nousevat sisällöt on otettu teoksen lähtökohdiksi. Sen aineisto on ilmaisuvoimainen ja rikas. Teoksessa myös koetellaan nykyisiä mielen teorioiden pääsuuntauksia ja nostetaan esille aikalaiskriittisiä äänenpainoja pyrkimällä paikantamaan uusia yhteiskunnallisia ilmiöitä. Sen tutkimuksellinen ote on kulttuurintutkimuksellinen ja inhimillisiä kokemuksia tiheästi kuvaileva.

\section{Kulttuurisen kontekstin painotuksia}

Vahvasti kulttuurisen kontekstin merkitystä painottavassa Susanne Ådahlin artikkelissa käsitellään havaintoon ja aistimiseen liittyviä kysymyksiä. Aineistona on Mieli ja toinen -projektin kirjeaineiston ohella ääniä kuulevien ihmisten parissa tehtyjä haastatteluja. Ådahl tuo esille muun muassa länsimaiseen tiedekäsitykseen perustuvan aistijärjestelmän ja niin sanotuissa ei-länsimaisissa yhteiskunnissa esiintyvien aistikokemusten välisiä eroja vertailevan kulttuurien tutkimuksen näkökulmasta. Aistikokemukset ovat moninaisia ja kulttuurisidonnaisia, kuten Ådahlin aineistoissa ja artikkelissa tarkastellut esimerkit osoittavat. Niin ikään Varpu 
Alasuutarin kirjoittamassa kappaleessa korostetaan erityislaatuisten kokemusten kulttuurisidonnaisuutta. Siinä tarkastellaan vainajakokemuksia ja erilaisia suremisen tapoja. Vainajakokemuksiin suhtautuminen on Alasuutarin mukaan yleensä sallivampaa kuin muihin kummina pidettyihin kokemuksiin. Kokemukset menehtyneiden läheisten kohtaamisesta tarjoavat tilaisuuden käsitellä ihmissuhteissa keskeneräisiksi jääneitä kysymyksiä.

Luvussa "Kumma ja tunteet" Kirsi Kanerva tarkastelee tunnetutkimuksen näkökulmasta tunteiden ja niiden ilmaisemisen kulttuurisuutta ja sitä, millaisia tunteita kummiin kokemuksiin nyky-Suomessa liitetään. Vaikka hänen analysoimaansa kirjeaineistoa ei ole kerätty nimenomaan tunnetutkimusta varten, voivat siinä esiintyvät tunnekuvaukset olla Kanervan mukaan tärkeä informaatiolähde, koska tunteista kertominen saattaa olla yksi keino kommunikoida erityislaatuisiksi mielletyistä kokemuksista. Luvussa nostetaan esille myös kiinnostava huomio tunnepuheen lisääntymisestä ja kulttuurin tunteistumisesta lähihistorian ilmiönä.

\section{Kummallisten kokemusten sosiaalisia ja historiallisia ulottuvuuksia}

Kaarina Kosken ja Juuso Järvenpään teksti kummien kokemusten tulkinnasta erittelee arkitodellisuudesta ja -ontologiasta poikkeavien arkaluontoisten ja stigmatisoitujen ilmiöiden ja kummien kokemusten moninaisuutta folkloristiikan ja historiantutkimuksen näkökulmista. Se luotaa kummien kokemusten synnyttämiä ristiriitoja niin kokijoiden itsensä kuin ulkopuolisten näkökulmista ja tarkastelee myös sopiviksi ja sopimattomiksi miellettyjä tapoja puhua edellä mainituista kokemuksista. Artikkelissa käsitellään kiinnostavasti David Huffordin (1982) esille nostamaa kysymystä "epäuskon traditioista" ja oletusta siitä, että yliluonnollisia elämyksiä ei ole olemassa.

Artikkelissaan Koski ja Järvenpää mainitsevat kulttuurintutkijoiden Martti Haavio ja Christfrid Ganander tavat torjua omaa leimautumistaan luonnehtimalla tarkastelemiaan yliluonnollisia elämyksiä hallusinaatioiksi tai kokijan "normaalitilaan" kuulumattomiksi ilmiöiksi. Perinteentutkimuksessa tällaisia kokemuksia on puolestaan tarkasteltu yhteisössä vallitsevien sosiaalisten roolien näkökulmasta (ks. esim. Honko 1972) tai neutraalin ymmärtämisen (Virtanen 1974) kautta. Stigmatisoitumista ajatellen on kiinnostavaa, miten viimeksi mainittu näkemys sai Kosken ja Järvenpään mukaan (s. 276) osakseen pääosin negatiivisia reaktioita (ks. myös Enges 2004). Honkasalo puolestaan erittelee tekstissään kummaa yhteiskunnallisena kokemuksena ja käytäntönä. Hän kietoo kysymyksen kummasta Latourin $(1999 ; 2005)$ näkemykseen toimijaverkostosta ja käsittelee sitä "suhteisuuden" näkökulmasta. Honkasalo havainnollistaa sitä, kuinka kummalliset kokemukset ovat osa ihmisten yhteiskunnallista yhdessä olemista sellaisilla alueilla, joita on tärkeää hahmottaa toisiinsa liittyvinä, ei niistä erillisinä ilmiöinä.

Jyrki Korkeila ja Kaarina Koski tarkastelevat artikkelissaan kummia kokemuksia, häpeäleimaa ja psykoosia psykiatrian näkökulmasta ja hallusinaation käsitteen kautta. He kirjoittavat, että yhteiskunnassamme käsitys normaaleista kokemisen tavoista on verrattain kapea. Se tulee esille kummallisia kokemuksia omaavien ihmisten mielisairaaksi leimaamisen pelossa ja muiden epäluulossa heitä kohtaan. Tutkimusaineistoinaan Korkeila ja Koski käyttävät kirjeaineistossa kuvattuja kummia kokemuksia ja kliinistä aineistoa, jossa diagnosoidut potilaat kuvaavat kokemuksiaan. Korkeila ja Koski tuovat esille myös kiinnostavan huomion siitä, että vaikka harhanäyt ja -luulot ovat yleisiä psykoosisairauden oireita, esiintyy epätavallisia kokemuksia kuitenkin väestössä psykoosisairauksia enemmän. He kuitenkin huomauttavat, että kummien kokemusten tarkkaa määrää tai yleisyyttä on viime kädessä haastavaa arvioida. 
Suomalaisen rajatiedon historiaa tarkastelevassa kappaleessa Juuso Järvenpää luo katsauksen suomalaisen uskontokentän tuntemattomampiin alueisiin historiantutkimuksellisesta ja uskontotieteen parissa esitettyjä käsityksiä hyödyntävästä näkökulmasta. Hän analysoi yhtäältä Suomessa 1800- ja 1900-luvun vaihdetta ympäröivinä vuosikymmeninä esiintyneitä okkulttisia liikkeitä. Toisaalta artikkelissa esitellään 1900-luvun jälkipuoliskolla ilmennyttä "new agea" ja siihen liittyviä ilmiöitä.

Teoksen loppuun sijoittuvat, Tiina Mahlamäen kirjoittamat tutkijan jälkisanat ja Riitta Jalosen kirjoittama kappale "Helmiä, ei häpeää" muodostavat kirjalle luontevat loppuluvut. Mahlamäki käsittelee tekstissään esoteriaa, kumman kokemusta ja sitä tarkastelevan tutkimuksen paikkaa traditioiden ulkopuolella ja marginaaleissa. Jalonen puolestaan kuvaa kappaleessaan kokemustaan taiteesta hyväksyttynä ja sellaisena "vapaampana kulkuvälineenä ulottuvuuksista toisiin" (s. 339), kun taas erikoislaatuisia kokemuksia omaavat ihmiset ovat saattaneet törmätä mitätöintiin, mikäli ovat niitä uskaltaneet tuoda esille.

\section{Tutkimuseettinen näkökulma}

Mielen rajoilla kuvaa kummallisia kokemuksia kohdanneiden ihmisten puheenvuoroja erikoisista kokemuksistaan. Teoksessa tuodaan esille, että erikoiset kokemukset paikantuvat nimenomaan niitä kokeneiden ihmisten omaan elämänhistoriaan ja kulttuuriin. Mielen rajoilla luotaa kummallisia kokemuksia monipuolisesti ja tässä mielessä hyvin perinteisen antropologisesti. Näin tehdessään se ei asetu kokijoiden yläpuolelle, vaan pyrkii antamaan tilaa tärkeiksi koetuille erityislaatuisille kokemuksille kuitenkaan ontologisiin kysymyksiin kantaa ottamatta. Tästä näkökulmasta Mielen rajoilla on paitsi kiinnostava antologia suomalaisessa nykykulttuurissa esiintyvistä erikoisista kokemuksista myös rohkea tutkimuseettinen puheenvuoro.

\section{Kirjallisuus}

Enges, Pasi 2004: Uskon ja epäuskon traditiot. Leea Virtanen, parapsykologia ja tutkijan suhde yliluonnolliseen. - Elore 11(1) [online] < http://wwww.elore.fi/arkisto/1 04/ eng104.html $>$ [6.3.2018.]

Honko, Lauri 1972: Uskontotieteen näkökulmia. Porvoo: WSOY.

Hufford, David 1982: Traditions of Disbelief. - New York Folklore 8: 47-55.

Latour, Bruno 1999: Pandora's Hope. Essays on the Reality of Science Studies. Cambridge: Harvard University Press.

Latour, Bruno 2005: Reassembling the Social. An Introduction to Actor-Network-Theory. Oxford: Oxford University Press.

Virtanen, Leea 1974: Kun kello pysähtyi. Tavallisen suomalaisen yliluonnolliset kokemukset. Helsinki: WSOY.

\section{Filosofian tohtori Leila Jylhänkangas on kulttuurintutkija ja psykologi.}

